\title{
How HTLV-I may subvert miRNAs for persistence and transformation
}

\author{
Amel B Bouzar ${ }^{1,2}$ and Luc Willems*1,2
}

\author{
Address: ${ }^{1}$ Molecular and Cellular Biology lab of the Gembloux Agricultural University (FUSAG)n ${ }^{\circ} 13$, avenue Maréchal Juin, 5030 Gembloux, \\ Belgium and ${ }^{2}$ Molecular and Cellular Epigenetics, Interdisciplinary Cluster for Applied Genoproteomics (GIGA) of University of Liège (ULg) \\ avenue de l'Hôpital n B34, Sart-Tilman, 4000 Liège, Belgium \\ Email: Amel B Bouzar - bouzar.a@fsagx.ac.be; Luc Willems* - willems.l@fsagx.ac.be \\ * Corresponding author
}

Published: 12 November 2008

Retrovirology 2008, 5:101 doi:10.1186/1742-4690-5-101

This article is available from: http://www.retrovirology.com/content/5/I/I0I

(c) 2008 Bouzar and Willems; licensee BioMed Central Ltd.

This is an Open Access article distributed under the terms of the Creative Commons Attribution License (http://creativecommons.org/licenses/by/2.0), which permits unrestricted use, distribution, and reproduction in any medium, provided the original work is properly cited.
Received: 3 November 2008

Accepted: 12 November 2008

\begin{abstract}
Distinct mechanisms are used by viruses to interact with cellular miRNAs. The role of microRNAs in viral replication and persistence ranges from viral-encoded microRNAs to suppressors of RNA interference. Viruses can also exploit cellular miRNAs for influencing cellular metabolism to ensure efficient replication or latency. In particular, two recent studies provide examples of how HTLV-I may co-opt or subvert cellular miRNAs for persistent replication and oncogenic purposes. The pathways modulated by these described miRNAs are critically involved in apoptosis, proliferation and innate immune response.
\end{abstract}

\section{Biogenesis of miRNAs}

MicroRNAs are initially transcribed by RNA polymerase II as a primary miRNA (pri-miRNA) transcript and processed in the nucleus by RNase III enzyme Drosha and its cofactor DGCR8 [1-4]. Cleavage of the pri-miRNA by the Drosha-DGCR8 heterodimer generates a 60-70 nucleotide precursor miRNA (pre-miRNA), which is then transported to the cytoplasm by the nuclear export factor exportin 5 and GTP-bound Ran. Cytoplasmic pre-miRNA is further recognized by RNase III enzyme Dicer bound to its cofactor TRBP, and the pre-miRNA is cleaved into a mature miRNA. Finally, loading of the miRNA into the RNA-induced silencing complex (RISC) allows the miRRISC to target cognate mRNA via imperfect base complementarity. miR-RISC can induce the cleavage of or may inhibit the translation of targeted mRNAs.

There is some promiscuity amongst the several hundreds of cellular miRNAs, each miRNA can potentially target many discrete mRNAs, thereby modulating a broad spec- trum of biological functions. Indeed, RNA interference is a major mechanism used to control viral infections in plants and invertebrates [4]. As a counter play to the cell's RNAi, viruses encode suppressors of RNA silencing, which target several key steps in the RNAi process $[5,6]$. Compelling evidence that this process also applies to mammalian cells and viruses is presently accumulating in the literature [7].

\section{Biological roles of virus-encoded non-coding RNAs}

The first evidence of virus-encoded miRNAs emerged from studies of Herpesviruses (e.g. Epstein-Barr virus encoded microRNAs $[8,9])$. These viral miRNAs exert a wide variety of functions ranging from stimulation of proliferation, inhibition of apoptosis, maintenance of latency, regulation of immune response and cellular metabolism. For example, miR-I encoded by the herpes simplex virus 2 (HSV 2) has a critical role in neurovirulence through modulation of ICP34.5 expression [10]. On the other 
hand, miR-K12-10 encoded by Kaposi sarcoma-associated herpesvirus (KSHV) plays a key role in cellular transformation through downregulation of Kaposin mRNA translation $[9,11]$. Non-herpesviruses such as Simian Virus 40 (SV40) can also encode a miRNA which reduces the susceptibility of infected cells to lysis by cytotoxic T cells, allowing the virus to evade the host immune response [12]. Additionally, adenovirus VA1 noncoding RNA is not a virus-encoded miRNA, but is able to subvert the cell's RNAi pathway by competing with cellular pre-miRNAs for exportin-5 in the nucleus as well as by binding Dicer in the cytoplasm [13]. VA1 RNA also interacts with PKR (interferon-inducible double-stranded RNA-dependent protein kinase), thereby blocking its activation and the subsequent phosphorylation of eukaryotic translationinitiation factor $2 \alpha(\mathrm{eIF} 2 \alpha)$.

\section{Viruses can be targeted by cellular miRNAs}

Given the prevalence of miRNA genes and the short sixnucleotide seed pairing that is needed to establish miRNA-mRNA interactions, viral genomes are also likely targets of human cellular miRNAs [14]. Initial evidence supporting this idea was illustrated by the binding of the host-cell's miRNA miR-32 to a site in primate foamy virus type 1 (PFV-1) RNA, which restricted viral RNA accumulation [15]. The PFV-1 Tas protein counteracted this mechanism and functioned as a silencing suppressor to relieve this repression and allowed PFV-1 replication.

Surprisingly, the interaction of viral genomes with cellular miRNAs may also promote rather than inhibit viral replication. Thus, the binding of liver-specific miR-122 to the 5 ' end of hepatitis $\mathrm{C}$ virus (HCV) RNA increased viral RNA levels, probably owing to a stimulation of viral replication or to the re-localization of viral RNA $[16,17]$. Interferonbeta (IFN $\beta$ ) treatment reduced miR-122 but increased the expression of miR-1/miR-30/miR-128/miR-196/miR296/miR-351/miR-431/miR-448 miRNAs [18]. Similarly, the introduction of synthetic miRNA mimics corresponding to these 8 miRNAs into cells reproduced the antiviral effects of IFN $\beta$ on HCV replication. Conversely, neutralization of these miRNAs reduced the antiviral effects of IFN $\beta$ against HCV. Moreover, inoculation of miR-122 antisense oligonucleotides into mice resulted in the inhibition of cholesterol biosynthesis and HCV replication $[19,20]$.

The ability of mammals to regulate retroviruses like HIV1 has been intensely debated $[3,21]$. Recent evidence that HIV-1 replication can be promoted by lowered expression of Dicer and Drosha supports a role of the miRNA silencing machinery in controlling viral infection [22]. In fact, the 3 ' ends of HIV-1 mRNAs are targeted by a cluster of cellular miRNAs (miR-28, miR-125b, miR-150, miR-223 and miR-382), which inhibit HIV-1 protein translation and viral production [23]. Since these miRNAs are upregulated in resting CD4+ T cells, the RNAi machinery may also contribute to viral latency. Given that specific inhibitors of these miRNAs substantially counteract their effects on the target mRNAs, RNA interference may potentially be useful for purging the HIV-1 reservoir of latent virus [24].

\section{Targeting of cellular miRNAs by HTLV-I}

Viruses can also exploit cellular miRNAs for influencing cellular metabolism, proliferation, apoptosis and, ultimately, transformation [2]. For example, the Epstein Barr virus (EBV) infection of human B lymphocytes increases miR-155 [25] and miR-146a [26] expression through a mechanism that, at least in part, involves latency membrane protein 1 (LMP1). Similarly, increased expression of the BIC/miR155 and other oncogenic miRNA transcripts in animal lymphomas due to retroviral integrations have also been documented [27-29]. However, despite the few examples of subversion of cellular miRNA by viruses, the field of viral oncogenesis mediated through miRNA-expression remains insufficiently explored. The papers by Pichler et al. [30] and by Yeung et al. [31] represent the first reports linking Human T-lymphotropic virus type 1 (HTLV-1) infection with the modulation of human miRNA expression.

HTLV-1 infects about 10-20 million people worldwide and, in a significant proportion of them $(\sim 2-4 \%)$, causes either adult T cell leukemia (ATL) or HAM/TSP (HTLVassociated myelopathy/Tropical Spastic Paraparesis). HTLV-1 infects and replicates in CD4+ and CD8+ T lymphocytes [32] as well as in dendritic cells [33]. HTLV-1 persistence and replication critically involves the virusencoded Tax protein $[34,35]$. Amongst a broad variety of functions, Tax activates transcription of viral and cellular genes (e.g. TNF- $\alpha$ ), accelerates cell cycle progression, interferes with apoptosis, inhibits checkpoints and induces DNA damage. To carry out these functions, Tax interacts with and modulates the activity of more than 100 cellular proteins (recently reviewed by Boxus et al [36]). The new findings from Pichler et al. and Yeung et al. add another level of complexity by identifying miRNAs as being either directly activated by Tax or associated with HTLV-1 induced cell transformation.

The approaches used to narrow down the spectrum of candidate miRNAs in the two studies were different. Pichler et al. selected a limited number of miRNAs having links with cancer and being overexpressed in regulatory $\mathrm{T}$ lymphocytes. Their rationale for miRNA selection was that the phenotype of Tregs resembles that of ATL cells. RT-PCR quantification identified upregulated (miR-21, miR-24, miR-146a, miR-155) and repressed (miR-223) miRNAs in a series of cell lines derived from ATL patients, HAM/TSP patients and HTLV-1 or Tax transformed cells. 
Expression of one of these, miR-146a, was directly activated by Tax through the proximal NF- $\kappa \mathrm{B}$ site of the MIRN146A gene promoter.

Yeung et al. profiled 327 human miRNAs in 7 HTLV-1 transformed cell lines and 4 PBMC samples from acute ATL patients. Among 15 miRNAs whose expression was consistently modified compared to paired controls, only 3 (miR-93, miR-130b and miR-18a) were also induced upon the activation of normal PBMCs with phorbol myristate acetate. The authors then confirmed the differential expression of miR-93 and miR-130b using qRT-PCR. Computational analysis and luciferase reporter assays demonstrated that the p53-inducible tumor suppressor protein (TP53INP1) was a target shared by both miR-93 and miR-130b. Consistently, antagomirs for miR-93 and miR-130b (used to knock down the level of miR-93 and miR-130b in cells) restored TP53INP1 expression and increased the apoptosis of HTLV-1 transformed MT4 cells. Conversely, siRNA knock-down of TP53INP1 rescued MT4 from cell death induced by the miR-93 and miR$130 \mathrm{~b}$ antagomirs. Increased expression of miR-130b occurs at least partly through transcriptional activation by Tax. Finally, Yeung et al. also reported a series of miRNAs that are repressed in ATL cells.

\section{HTLV-I upregulates miRNAs involved in proliferation, apoptosis and immune response} Although technical procedures and methodological approaches were different, several identical miRNA changes were identified in both studies. Given the complexity of the biological processes and the reported datasets, we focus in figure 1 on a selected number of relevant miRNAs reported in the two studies that are overexpressed in ATL (miR-93, miR-130b, miR-155 and miR-146a). These miRNAs target genes (TP53INP1, SMAD5, IRAK6/ TRAF1) are involved in apoptosis, cell proliferation or transformation, and the regulation of immune response.

A first salient outcome from the Pichler and Yeung reports is that HTLV-1 directly modulates the expression of at least two miRNAs by transactivating the miR-130b and miR-146a promoters. These data show examples of how viruses may directly modulate the transcription of cellular miRNAs, possibly to favor replication and/or oncogenicity. Considering that the HTLV-1 Tax protein is known to activate a very long list of genes through NFKB/CREB/SRF [35], it is expected that additional miRNAs could be directly modulated by Tax, through the transactivation of their cognate promoters. We can also speculate whether other steps in the biogenesis of miRNA may be under the control of HTLV-1 encoded proteins, such as Rex for nuclear export or NC for encapsidation. Further investigations are definitely required to test these predictions.

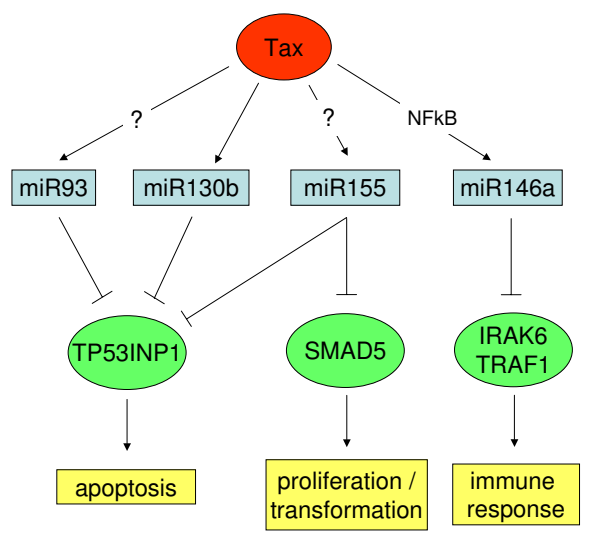

Figure I

Overview of 4 miRNAs overexpressed in ATL cells and their targeted mRNAs: TP53INPI, Smad5 and IRAK6/TRAFI. These genes are critically involved in pathways important for viral persistence and oncogenicity. Tax directly transactivates the miR-I46a (through a NF- $\mathrm{kB}$ site) and miR-I30b promoters. Only one of these pathways $\mathrm{Tax} \rightarrow \mathrm{miRI} 30 \mathrm{~b} \rightarrow$ TP53INPI $\rightarrow$ apoptosis has presently been demonstrated functionally.

A second striking observation is that a single transcript (i.e. TP53INP1) is targeted by 3 different miRNAs (miR93, miR130b and miR155) that are overexpressed in ATL cells. TP53INP1, whose transcription is activated by $\mathrm{p} 53$, induces cell cycle arrest in G1 and enhances p53-mediated apoptosis [37]. The role of TP53INP1 in oncogenesis has been reported in a series of models. In pancreatic cancer, TP53INP1 is repressed by miR-155, and its restoration inhibits tumor development [1]. Growth of colorectal tumors is exacerbated in TP53INP1-deficient mice [38]. TP53INP1's expression is reduced during the development of breast cancer [39], gastric cancer [40], pancreatic cancer [1] and melanoma [41], but curiously increased in thyroid cancer [42]. The convergence of multiple miRNAs onto a single target reinforces the idea that TP53INP1 could also be a relevant factor for HTLV-1 leukemogenesis.

Besides its effects on TP53INP1, miR155 also targets genes critically involved in cellular proliferation and transformation. In fact, higher expression of miR-155 has been exemplified in several types of hematopoietic malignancies including B-cell and Hodgkin's lymphoma $[4,43,44]$. Overexpression of miR-155 causes myeloproliferative disorders or B cell lymphoma in mouse models. Mice lacking miR-155 exhibit defective humoral responses after immunization, consistent with a specialized function for miR155 during infection $[45,46]$. In T lymphocytes, miR-155 regulates $\mathrm{T}$ cell lineage fate by promoting $\mathrm{T}$ helper type 1 
(Th1) versus T helper type 2 (Th2) differentiation. BIC/ miR-155 is overexpressed in Treg cells, consecutive to Foxp3-induced promoter activation. Consistent with its association with an activated $\mathrm{T}$ cell phenotype, miR-155 is absent from the HIV-1 latent reservoir [23]. miR-155 is also involved in lymphocyte activation and the latency of Epstein-Barr virus (EBV)-infected cells [47]. miR-155 expression in EBV-infected cells is dependent on NF- $\mathrm{KB}$ signaling and requires a conserved AP-1 element in the miR-155 promoter. Using luciferase reporter systems, Smad5 was confirmed as a gene under the control of miR155 [47]. Smad5 is one of the 5 receptor-regulated Smads which orchestrate transforming growth factor $\beta$ (TGF $\beta$ ) signaling. TGF $\beta$ induces miR-155 expression and promoter activity through Smad4 [48]. Conversely, the knockdown of miR-155 suppresses TGF $\beta$-induced cell migration and invasion [49]. The involvement of miR155 in ATL further complicates the interplay between HTLV-1 and the TGF $\beta$ pathway [50-52] but underscores its critical role in transformation.

Another key player overexpressed in HTLV-1-infected ATL cells is miR-146a. This miRNA was first identified as an immune system regulator induced by lipopolysaccharide (LPS) and proinflammatory cytokines (such as interleukin 1 and tumor necrosis factor) [53,54]. miR-146 is among the most highly expressed miRNAs in regulatory $\mathrm{T}$ cells. Compared to Th2 and naïve T cells, miR-146 levels are higher in Th1 cells. Amongst the growing list of confirmed target genes of mir-146, IRAK1 and TRAF6 adaptor molecules are essential for Toll-like receptor and interleukin 1 receptor signaling $[55,56]$. Reduction of IRAK1 and TRAF6 expression might therefore be involved in the regulation of the innate immune response.

\section{Conclusion}

HTLV-1 has not yet been shown to encode a viral miRNA, although potential candidate genes such as $\mathrm{Hbz}[57,58]$ have not been sufficiently evaluated. In this context, it is intriguing that the Hbz RNA, but not its encoded proteins, promotes $T$ cell proliferation [59]. Could this activity be through an RNA-mediated mechanism similar to RNA interference? The papers by Pichler et al [30] and Yeung et al. [31] demonstrate how HTLV-1 modulates a series of miRNAs, although only a few of them are commented on here. What has not been mentioned here but should be stressed is that a number of miRNAs are repressed in ATL cells such as let-7 (a tumor repressor of Ras and Myc transformation) or miR34b (inducing cell cycle arrest), further amplifying the complexity of HTLV-1's interaction with miRNAs in the transformation pathways. In another perspective, it could also be considered that HTLV-1 persists in a limited population of cells characterized by a given miRNA profile. This view of opportunistic viral persistence has recently been illustrated for how HIV-1 latently

$$
\text { HTLV-1 }
$$

Host cell

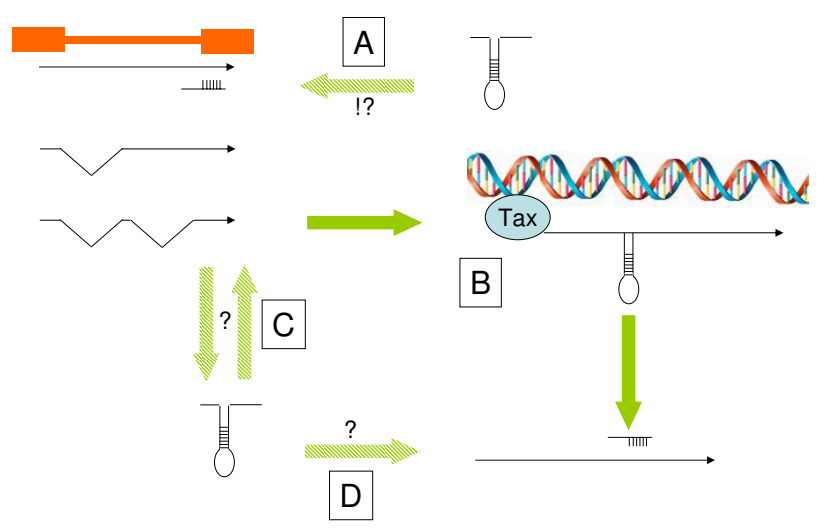

Figure 2

Confirmed and hypothetical (?) interplays between HTLV-I and virus or cell-derived small non-coding RNAs. A. Given the imperfect base-pairing requirements, the multiplicity of cellular miRNAs and the length of the proviral genome, it seems likely (!?) that HTLV-I is targeted by cellular miRNAs. B. HTLV-I Tax directly transactivates cellular miRNA genes. Expression of a small non-coding viral RNA by HTLV-I could affect viral (C) or cellular (D) gene expression through hypothetical (?) mechanisms of RNA interference.

infects resting CD4 T-cells [23]. Further investigations of confirmed and speculative interplays between HTLV-1 and small non-coding RNAs (figure 2) are merited.

\section{Competing interests}

The authors declare that they have no competing interests.

\section{Authors' contributions}

$\mathrm{AB}$ and $\mathrm{LW}$ collected data from the literature and wrote the paper. All authors read and approved the final manuscript.

\section{Acknowledgements}

We thank the "FONDS NATIONAL DE LA RECHERCHE SCIENTIFIQUE" (FNRS), the Télévie foundation, the Belgian Foundation against Cancer, the Sixth Research Framework Programme of the European Union (project INCA LSHC-CT-2005-018704) and the Bekales Foundation for financial support. $A B B$ is the senior research assistant of the "Action de Recherche Concertée" of the "Communauté Française de Belgique" and LW is a "Research Director" of the FNRS. We are grateful to KT Jeang, Arsène Burny and Mathieu Boxus for their comments. We would like to dedicate this commentary to the memory of Ralph Grassmann.

\section{References}

I. Gironella M, Seux M, Xie MJ, Cano C, Tomasini R, Gommeaux J, Garcia S, Nowak J, Yeung ML, Jeang KT, Chaix A, Fazli L, Motoo Y, Wang Q, Rocchi P, Russo A, Gleave M, Dagorn JC, lovanna JL, Carrier A, Pébusque MJ, Dusetti NJ: Tumor protein 53 -induced nuclear 
protein I expression is repressed by $\mathrm{miR}-\mathrm{I55}$, and its restoration inhibits pancreatic tumor development. Proc Natl Acad Sci USA 2007, 104:16170-16175.

2. Scaria $\mathrm{V}$, Jadhav $\mathrm{V}$ : microRNAs in viral oncogenesis. Retrovirology 2007, 4:82.

3. Yeung ML, Benkirane M, Jeang KT: Small non-coding RNAs, mammalian cells, and viruses: regulatory interactions? Retrovirology 2007, 4:74

4. Baltimore D, Boldin MP, O'Connell RM, Rao DS, Taganov KD MicroRNAs: new regulators of immune cell development and function. Nat Immunol 2008, 9:839-845.

5. Voinnet O, Pinto YM, Baulcombe DC: Suppression of gene silencing: a general strategy used by diverse DNA and RNA viruses of plants. Proc Natl Acad Sci USA 1999, 96:14|47-14152.

6. Roth BM, Pruss GJ, Vance VB: Plant viral suppressors of RNA silencing. Virus Res 2004, I 02:97-108.

7. Grassmann $\mathrm{R}$, Jeang $\mathrm{K}$ : The roles of microRNAs in mammalian virus infection. Biochim Biophys Acta 2008, I 779:706-7I I.

8. Pfeffer S, Zavolan M, Grässer FA, Chien M, Russo JJ, Ju J, John B, Enright AJ, Marks D, Sander C, Tuschl T: Identification of virusencoded microRNAs. Science 2004, 304:734-736.

9. Pfeffer S, Sewer A, Lagos-Quintana M, Sheridan R, Sander C, Grässer FA, van Dyk LF, Ho CK, Shuman S, Chien M, Russo J], Ju J, Randall G, Lindenbach BD, Rice CM, Simon V, Ho DD, Zavolan M, Tuschl T: Identification of microRNAs of the herpesvirus family. Nat Methods 2005, 2:269-276.

10. Tang S, Bertke AS, Patel A, Wang K, Cohen JI, Krause PR: An acutely and latently expressed herpes simplex virus 2 viral microRNA inhibits expression of ICP34.5, a viral neurovirulence factor. Proc Natl Acad Sci USA 2008, I 05: I093 I-I 0936.

II. Cai X, Lu S, Zhang Z, Gonzalez CM, Damania B, Cullen BR: Kaposi's sarcoma-associated herpesvirus expresses an array of vira microRNAs in latently infected cells. Proc Natl Acad Sci USA 2005, 102:5570-5575.

12. Sullivan CS, Grundhoff AT, Tevethia S, Pipas JM, Ganem D: SV40encoded microRNAs regulate viral gene expression and reduce susceptibility to cytotoxic T cells. Nature 2005 , 435:682-686.

13. Lu S, Cullen BR: Adenovirus VAI noncoding RNA can inhibit small interfering RNA and MicroRNA biogenesis. J Virol 2004 78: $12868-12876$

14. Watanabe Y, Kishi A, Yachie N, Kanai A, Tomita M: Computational analysis of microRNA-mediated antiviral defense in humans. FEBS Lett 2007, 58 I:4603-4610.

15. Lecellier $\mathrm{CH}$, Dunoyer $\mathrm{P}$, Arar $\mathrm{K}$, Lehmann-Che J, Eyquem S, Himber C, Saïb A, Voinnet O: A cellular microRNA mediates antiviral defense in human cells. Science 2005, 308:557-560.

16. Jopling CL, Yi M, Lancaster AM, Lemon SM, Sarnow P: Modulation of hepatitis $C$ virus RNA abundance by a liver-specific MicroRNA. Science 2005, 309:|577-|58|

I7. Jopling CL, Schutz S, Sarnow P: Position-dependent function for a tandem microRNA miR-I22-binding site located in the hepatitis C virus RNA genome. Cell Host Microbe 2008, 4:77-85.

18. Pedersen IM, Cheng G, Wieland S, Volinia S, Croce CM, Chisari FV, David $M$ : Interferon modulation of cellular microRNAs as an antiviral mechanism. Nature 2007, 449:919-922.

19. Kapadia SB, Chisari FV: Hepatitis $\mathbf{C}$ virus RNA replication is regulated by host geranylgeranylation and fatty acids. Proc Nat Acad Sci USA 2005, 102:256|-2566.

20. Ye J, Wang C, Sumpter R Jr, Brown MS, Goldstein JL, Gale M Jr: Disruption of hepatitis $C$ virus $R N A$ replication through inhibition of host protein geranylgeranylation. Proc Natl Acad Sci USA 2003, I 00: I5865-15870.

21. Cullen BR: Is RNA interference involved in intrinsic antiviral immunity in mammals? Nat Immunol 2006, 7:563-567.

22. Triboulet R, Mari B, Lin YL, Chable-Bessia C, Bennasser Y, Lebrigand K, Cardinaud B, Maurin T, Barbry P, Baillat V, Reynes J, Corbeau P, Jeang KT, Benkirane M: Suppression of microRNA-silencing pathway by HIV-I during virus replication. Science 2007 3 I5: I579- I582.

23. Huang J, Wang F, Argyris E, Chen K, Liang Z, Tian H, Huang W, Squires $\mathrm{K}$, Verlinghieri $\mathrm{G}$, Zhang $\mathrm{H}$ : Cellular microRNAs contribute to HIV-I latency in resting primary CD4+ $T$ lymphocytes. Nat Med 2007, I3:124I-1247.

24. Han Y, Siliciano RF: Keeping quiet: microRNAs in HIV-I latency. Nat Med 2007, I 3: I I 38- I I40.
25. Lu F, Weidmer A, Liu CG, Volinia S, Croce CM, Lieberman PM: Epstein-Barr virus-induced miR-I55 attenuates NF-kappaB signaling and stabilizes latent virus persistence. J Virol 2008 , 82: 10436-10443

26. Motsch N, Pfuhl T, Mrazek J, Barth S, Grasser FA: Epstein-Barr virus-encoded latent membrane protein I (LMPI) induces the expression of the cellular microRNA miR-I46a. RNA Biol 2007, 4: $|3|-137$.

27. Tam W: Identification and characterization of human BIC, a gene on chromosome 21 that encodes a noncoding RNA. Gene 200I, 274:I57-I67.

28. Lum AM, Wang BB, Li L, Channa N, Bartha G, Wabl M: Retroviral activation of the mir-I06a microRNA cistron in $T$ lymphoma. Retrovirology 2007, 4:5

29. Beck-Engeser GB, Lum AM, Huppi K, Caplen NJ, Wang BB, Wabl M: Pvtl-encoded microRNAs in oncogenesis. Retrovirology 2008, 5:4.

30. Pichler K, Schneider G, Grassmann R: MicroRNA miR-I46a and further oncogenesis-related cellular microRNAs are dysregulated in HTLV-I transformed T lymphocytes. Retrovirology 2008, 5:100.

31. Yeung ML, Yasunaga J, Bennasser Y, Dusetti N, Harris D, Ahmad N, Matsuoka M, Jeang KT: Roles for MicroRNAs, miR-93 and miRI30b, and Tumor Protein 53-Induced Nuclear Protein I Tumor Suppressor in Cell Growth Dysregulation by Human T-Cell Lymphotrophic Virus I. Cancer Res 2008, 68:8976-8985.

32. Hanon E, Stinchcombe JC, Saito M, Asquith BE, Taylor GP, Tanaka Y, Weber JN, Griffiths GM, Bangham CR: Fratricide among CD8(+) $T$ lymphocytes naturally infected with human $T$ cell lymphotropic virus type I. Immunity 2000, I 3:657-664.

33. Jones KS, Petrow-Sadowski C, Huang YK, Bertolette DC, Ruscetti FW: Cell-free HTLV-I infects dendritic cells leading to transmission and transformation of CD4(+) T cells. Nat Med 2008, 14:429-436.

34. Twizere JC, Kruys V, Lefèbvre L, Vanderplasschen A, Collete $D$, Debacq C, Lai WS, Jauniaux JC, Bernstein LR, Semmes OJ, Burny A, Blackshear PJ, Kettmann R, Willems L: Interaction of retroviral Tax oncoproteins with tristetraprolin and regulation of tumor necrosis factor-alpha expression. J Natl Cancer Inst 2003, 95: 1846-1859.

35. Matsuoka M, Jeang KT: Human T-cell leukaemia virus type I (HTLV-I) infectivity and cellular transformation. Nat Rev Cancer 2007, 7:270-280.

36. Boxus M, Twizere JC, Legros S, Dewulf JF, Kettmann R, Willems L: The HTLV-I Tax interactome. Retrovirology 2008, 5:76.

37. Tomasini R, Seux M, Nowak J, Bontemps C, Carrier A, Dagorn JC, Pébusque MJ, lovanna JL, Dusetti NJ: TP53INPI is a novel p73 target gene that induces cell cycle arrest and cell death by modulating p73 transcriptional activity. Oncogene 2005, 24:8093-8104.

38. Gommeaux J, Cano C, Garcia S, Gironella M, Pietri S, Culcasi M, Pébusque MJ, Malissen B, Dusetti N, lovanna J, Carrier A: Colitis and colitis-associated cancer are exacerbated in mice deficient for tumor protein 53-induced nuclear protein I. Mol Cell Biol 2007, 27:22 I5-2228.

39. Ito $\mathrm{Y}$, Motoo $\mathrm{Y}$, Yoshida H, lovanna JL, Takamura $\mathrm{Y}$, Miya A, Kuma K, Miyauchi A: Decreased expression of tumor protein p53induced nuclear protein I (TP53INPI) in breast carcinoma. Anticancer Res 2006, 26:4391-4395.

40. Jiang PH, Motoo Y, Garcia S, lovanna JL, Pebusque MJ, Sawabu N: Down-expression of tumor protein p53-induced nuclear protein I in human gastric cancer. World J Gastroenterol 2006, | 2:69|-696.

4I. Bonazzi VF, Irwin D, Hayward NK: Identification of candidate tumor suppressor genes inactivated by promoter methylation in melanoma. Genes Chromosomes Cancer 2009, 48(I): I0-2I.

42. Ito $Y$, Motoo $Y$, Yoshida $H$, lovanna JL, Nakamura $Y$, Kuma K, Miyauchi A: High level of tumour protein p53-induced nuclear protein I (TP53INPI) expression in anaplastic carcinoma of the thyroid. Pathology 2006, 38:545-547.

43. Eis PS, Tam W, Sun L, Chadburn A, Li Z, Gomez MF, Lund E, Dahlberg JE: Accumulation of miR-I 55 and BIC RNA in human B cell lymphomas. Proc Natl Acad Sci USA 2005, I 02:3627-3632.

44. Kluiver J, Poppema S, de Jong D, Blokzijl T, Harms G, Jacobs S, Kroesen BJ, Berg $A$ van den: BIC and miR-I55 are highly 
expressed in Hodgkin, primary mediastinal and diffuse large B cell lymphomas. J Pathol 2005, 207:243-249.

45. Rodriguez A, Vigorito E, Clare S, Warren MV, Couttet P, Soond DR, van Dongen S, Grocock RJ, Das PP, Miska EA, Vetrie D, Okkenhaug K, Enright AJ, Dougan G, Turner M, Bradley A: Requirement of bicl microRNA-I55 for normal immune function. Science 2007, 3 |6:608-6II.

46. Thai TH, Calado DP, Casola S, Ansel KM, Xiao C, Xue Y, Murphy A, Frendewey D, Valenzuela D, Kutok JL, Schmidt-Supprian M, Rajewsky N, Yancopoulos G, Rao A, Rajewsky K: Regulation of the germinal center response by microRNA-155. Science 2007, 3 16:604-608.

47. Yin Q, McBride J, Fewell C, Lacey M, Wang X, Lin Z, Cameron J, Flemington EK: MicroRNA- 155 is an Epstein-Barr virus-induced gene that modulates Epstein-Barr virus-regulated gene expression pathways. J Virol 2008, 82:5295-5306.

48. Kong W, Yang H, He L, Zhao J], Coppola D, Dalton WS, et al.: MicroRNA-I55 Is Regulated by TGF\{beta\}/Smad Pathway and Contributes to Epithelial Cell Plasticity by Targeting RhoA. Mol Cell Biol 2008, 28:6773-6784.

49. Daly AC, Randall RA, Hill CS: TGF-\{beta\}-induced SmadI/5 phosphorylation in epithelial cells is mediated by novel receptor complexes and is essential for anchorage-independent growth. Mol Cell Biol 2008, 28:6889-6902.

50. Arnulf B, Villemain A, Nicot C, Mordelet E, Charneau P, Kersual J, Zermati Y, Mauviel A, Bazarbachi A, Hermine O: Human T-cell lymphotropic virus oncoprotein Tax represses TGF-beta I signaling in human $\mathbf{T}$ cells via c-Jun activation: a potential mechanism of HTLV-I leukemogenesis. Blood 2002 100:4129-4I38.

51. Mori N, Morishita M, Tsukazaki T, Giam CZ, Kumatori A, Tanaka Y, Yamamoto N: Human T-cell leukemia virus type I oncoprotein Tax represses Smad-dependent transforming growth factor beta signaling through interaction with CREB-binding protein/p300. Blood 200I, 97:2I37-2I 44 .

52. Lee DK, Kim BC, Brady JN, Jeang KT, Kim SJ: Human T-cell lymphotropic virus type I tax inhibits transforming growth factor-beta signaling by blocking the association of Smad proteins with Smad-binding element. J Biol Chem 2002 277:33766-33775.

53. Taganov KD, Boldin MP, Chang KJ, Baltimore D: NF-kappaBdependent induction of microRNA miR-146, an inhibitor targeted to signaling proteins of innate immune responses. Proc Natl Acad Sci USA 2006, 103:1248I-12486.

54. Dai R, Phillips RA, Zhang Y, Khan D, Crasta O, Ahmed SA: Suppression of LPS-induced IFN\{gamma\} and nitric oxide in splenic lymphocytes by select estrogen-regulated miRNA: A novel mechanism of immune modulation. Blood 2008 in press.

55. Kawai T, Akira S: Signaling to NF-kappaB by Toll-like receptors. Trends Mol Med 2007, I 3:460-469.

56. Jazdzewski K, Murray EL, Franssila K, Jarzab B, Schoenberg DR, de la CA: Common SNP in pre-miR-146a decreases mature miR expression and predisposes to papillary thyroid carcinoma. Proc Natl Acad Sci USA 2008, 105:7269-7274.

57. Cavanagh MH, Landry S, Audet $B$, Arpin-André $C$, Hivin P, Paré ME, Thête J, Wattel E, Marriott S], Mesnard JM, Barbeau B: HTLV-I antisense transcripts initiating in the 3'LTR are alternatively spliced and polyadenylated. Retrovirology 2006, 3:15.

58. Usui T, Yanagihara K, Tsukasaki K, Murata K, Hasegawa H, Yamada $Y$, Kamihira S: Characteristic expression of HTLV-I basic zipper factor (HBZ) transcripts in HTLV-I provirus-positive cells. Retrovirology 2008, 5:34.

59. Satou Y, Yasunaga J, Yoshida M, Matsuoka M: HTLV-I basic leucine zipper factor gene mRNA supports proliferation of adult $\mathbf{T}$ cell leukemia cells. Proc Natl Acad Sci USA 2006, 103:720-725.

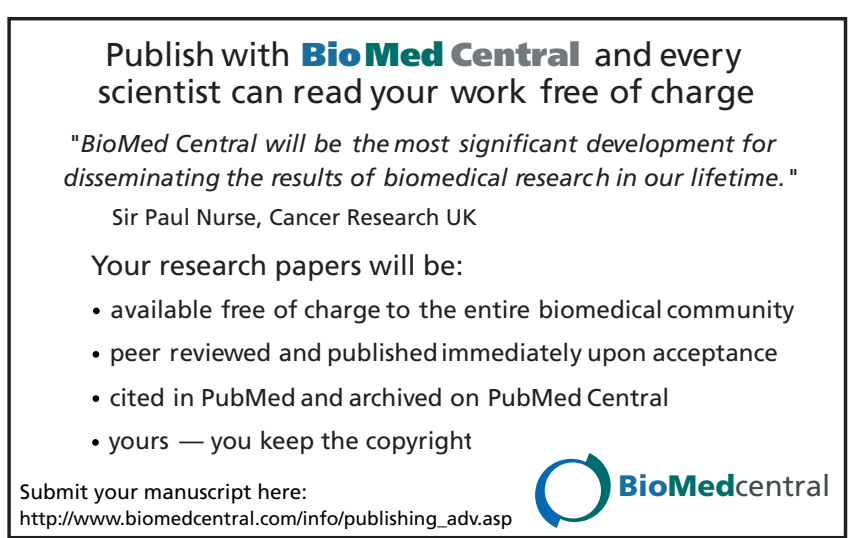

